University of Nebraska - Lincoln

DigitalCommons@University of Nebraska - Lincoln

Faculty Papers and Publications in Animal

Science

Animal Science Department

2007

\title{
Production and Economic Comparisons of Two Calving Dates for Beef Cows in the Nebraska Sandhills
}

\author{
M. C. Stockton \\ University of Nebraska-Lincoln, matt.stockton@unl.edu \\ D. C. Adams \\ University of Nebraska, North Platte, dadams1@unl.edu \\ R. K. Wilson \\ University of Nebraska-Lincoln, rwilson6@unl.edu \\ T. J. Klopfenstein \\ University of Nebraska-Lincoln, tklopfenstein1@unl.edu \\ R. T. Clark \\ University of Nebraska-Lincoln
}

See next page for additional authors

Follow this and additional works at: https://digitalcommons.unl.edu/animalscifacpub

Part of the Animal Sciences Commons

Stockton, M. C.; Adams, D. C.; Wilson, R. K.; Klopfenstein, T. J.; Clark, R. T.; and Carriker, G. L., "Production and Economic Comparisons of Two Calving Dates for Beef Cows in the Nebraska Sandhills" (2007). Faculty Papers and Publications in Animal Science. 780.

https://digitalcommons.unl.edu/animalscifacpub/780

This Article is brought to you for free and open access by the Animal Science Department at DigitalCommons@University of Nebraska - Lincoln. It has been accepted for inclusion in Faculty Papers and Publications in Animal Science by an authorized administrator of DigitalCommons@University of Nebraska Lincoln. 


\section{Authors}

M. C. Stockton, D. C. Adams, R. K. Wilson, T. J. Klopfenstein, R. T. Clark, and G. L. Carriker 


\title{
$\sqrt{111}$ \\ Production and Economic Comparisons of Two Calving Dates for Beef Cows in the Nebraska Sandhills
}

\author{
M. C. Stockton, ${ }^{* 1}$ D. C. Adams, † R. K. Wilson, ${ }^{*}$ T. J. Klopfenstein, $¥$ R. T. Clark, ${ }^{*}$ \\ and G. L. Carriker§ \\ *Agricultural Economics Department, University of Nebraska, North Platte 69101; †Animal Science \\ Department, University of Nebraska, North Platte 69101; $\ddagger$ Animal Science Department, University of \\ Nebraska, Lincoln 68583; §University of Missouri Extension in Christian County, University of \\ Missouri, Ozark 65721
}

\begin{abstract}
Calving date for 120 cows in the Nebraska Sandhills was changed from the traditional calving season beginning March 15 (d 75) to one beginning June 15 (d 167) to match increased nutrient needs for lactating cows to immature grazed forages that are high in protein and energy. The hypotheses being tested were that 1) less hay and purchased feeds would be required, 2) production costs would be reduced, and 3) net returns would be greater for June-calving cows compared with their March-calving counterparts. All steer calves from 75 March-calving cows were moved to a feedlot within $60 \mathrm{~d}$ of weaning (March calf-feds). Half the steer calves from the 120 June-calving herd were moved within $60 \mathrm{~d}$ of weaning to a feedlot to be finished (June calf-feds) and the other half were moved to a feedlot in September after summer grazing of Sandhills rangeland (June yearlings). Half of the June-calving cows were bred on subirri-
\end{abstract}

\footnotetext{
${ }^{1}$ Corresponding author: mstockton2@unl.edu
}

gated regrowth (Meadow) and half on upland range. Data on 4 consecutive calf crops were collected through harvest with an additional year collected to feedlot placement. Results showed that fed hay was reduced from 1.79 to 0.10 metric tons per cow annually for the June-calving system. Cost and return analyses were conducted by production phases on steer calves. Production costs for both June-calving groups were less and net returns higher when compared with the March-calved group. The highest net return for a calf group was for the June yearlings from cows bred on subirrigated regrowth.

Key words: beef cow, calving date, Nebraska Sandhills

\section{INTRODUCTION}

The amount of harvested and purchased feeds required to sustain a cow herd in the Nebraska Sandhills is directly related to calving date (Adams et al., 1996; Clark et al., 2004). Cows calving in February and March cause lactation to occur in early spring when the range resource is dormant and low in protein and energy.
Effects of low protein and energy are generally mitigated by feeding harvested feeds. In contrast, a dry, gestating cow requires little or no supplementation during this same time period. Producers who began calving during the first half of April reported feeding $758 \mathrm{~kg} / \mathrm{yr}$ of hay per cow compared with $1,486 \mathrm{~kg} / \mathrm{yr}$ of hay for those who began calving during the last half of February (Clark et al., 2004).

Lower costs result from feeding less hay and protein supplement. Studies in Nebraska and other Great Plains states have demonstrated that calving late in the spring reduced the amount of hay and supplements fed and improved potential profitability (Deutscher et al., 1991; Klopfenstein, 1991; May et al., 1999; Clark et al., 2004).

Market timing is another factor that affects profitability. Calves and cull cows from June-calving herds may be sold when the market's average seasonal prices are highest. The average seasonal prices are lowest when calves and culls are normally sold from herds calved in March. 
June-born calves that graze summer range as yearlings may provide another advantage over March-born calves; they do not have to be held over most of the winter before the grazing season begins. A low-quality diet that limits gains is usually used for wintering March-born calves. Increased gains due to compensatory growth during the summer grazing season may offset some of the wintering costs; however, research has shown feedlot finishing performance was affected by previous nutrition, particularly as it related to grazing programs (Mader et al., 1989).

Our objectives were to determine if harvested or purchased feeds, or both, and labor could be reduced by matching lactation (i.e., calving date) with nutrient content of grazed forages in beef cow-calf systems, and to evaluate the economics of March vs. June calving systems. We hypothesized that a June calving season would match the increased nutrient requirements associated with lactation and late gestation with greater nutrient content of immature growing plants, extending grazing compared with the traditional March calving season and permitting a decrease in hay fed with a corresponding reduction in cost of production. We also hypothesized that costs associated with a June-calving system would be lower and net returns, revenues minus costs, would be higher than those for the March-calving system.

\section{MATERIALS AND METHODS}

\section{Production Systems}

In 1993, cows from a March-calving cow herd were bred to calve beginning either March 15, d 75 (75 cows) or June 15, d 167 (120 cows). Cows were blocked by age and randomly assigned to 1 of the 2 systems. All steer calves from March-calving cows were finished as calf-feds, and were moved shortly after weaning directly to the feedlot for finishing. One-half of the steer calves from
June-calving system were finished as calf-feds and the remainder grazed Sandhills range as yearlings the summer after they were weaned before being finished. All calf-feds were placed in a feedlot $243 \mathrm{~d}$ after the beginning of the calving season. Steers that were summer grazed as yearlings entered the feedlot $454 \mathrm{~d}$ after the start of the June calving season in which they were born. Calving dates, weaning dates, and feeding periods are given in Table 1. Heifer calves were developed for replacements so no postweaning data was available for them.

The length of the breeding season was $60 \mathrm{~d}$ for the March-calving system and $45 \mathrm{~d}$ for the June-calving system. A 60-d breeding season for March-calving cows is common to western Nebraska. A 45-d breeding season was implemented for the June-calving cows because late-born calves were considered to be at risk when early winter storms occur.

June-calving cows were divided into 2 groups of 60 for the breeding season. One group was bred on subirrigated meadow regrowth, and the other group was bred on upland range.

Pregnancy and weaning rates for both systems are found in Table 2 . Because of the longer length between parturition and rebreeding for cows transitioning to the June-calving system, the first year pregnancy rates (1993 to 1994) were not included in the analysis.

Animal production and resource use (i.e., grazing, feed, and labor) records were maintained on each herd from breeding to harvest for 4 production cycles (1993 to 1999). Records on the fifth cycle are abbreviated and only include breeding to feedlot placement (1997 to 1999). Table 3 contains the averages of these data.

March-calving cows were fed hay from subirrigated meadows from mid-January through April. June-calving cows were fed meadow hay for 3 $\mathrm{d}$ after weaning and during a winter storm in February 1996.

March-born calves were weaned after September 15 (d 259) and before
October 6 (d 280), and the steers were shipped to the feedlot in midNovember and harvested at $1.27 \mathrm{~cm}$ of backfat. June-born calves were weaned in early January. Half of the steer calves were shipped to the feedlot in mid-February, finished as calffeds, and harvested at $1.27 \mathrm{~cm}$ of backfat. The other half of the Juneborn steer calves grazed subirrigated meadow for approximately $90 \mathrm{~d}$ until they were moved to upland pasture in June. These June-born steers remained on upland pasture until midSeptember when they were shipped, as yearlings, to the feedlot. They were then harvested at $1.27 \mathrm{~cm}$ of backfat.

All animals were weighed at birth, weaning, feedlot placement, and harvest. Yearling steers were also weighed when they were moved onto grass for summer grazing. Analyses of variance were used to compare the annual averages weights for the 3 groups of calf-feds. The means and standard deviations are summarized in Table 4. This table includes results for heifers through weaning and steers through harvest. Student $t$-tests were used to compare the annual averages between range and meadow treatments for the yearling steers. The means and standard deviations for these treatments are in Table 5. The results for the yearling steers were identical to the June-born calf-feds through weaning and so were not included in Table 5.

\section{Costs and Returns Analyses}

Cost budgets were developed for each phase of production for each system. Budgets were based on the average resources consumed during 3 phases using 1998 resource prices (USDA, 2000). All budgets included costs for harvesting hay, feed purchases, grazing (e.g., maintenance of fences and water facilities), labor, operating interest, management, overhead, and heifer replacement, but did not include charges for land, property taxes, insurance, or buildings. The ownership costs for only hay harvesting and feeding equipment were included in 
Table 1. Approximate dates for key activities in the March ${ }^{1}$ and June ${ }^{2}$ calving systems

\begin{tabular}{|c|c|c|c|}
\hline \multirow[b]{2}{*}{ Activity } & \multirow{2}{*}{$\begin{array}{c}\text { March } \\
\text { Calf-feds }\end{array}$} & \multicolumn{2}{|c|}{ June } \\
\hline & & Calf-feds & Yearlings 4 \\
\hline Breed cows & $\begin{array}{l}\text { June } 5 \text { to August } 4 \\
\text { d } 157 \text { to } 217\end{array}$ & $\begin{array}{l}\text { September } 5 \text { to October } 20 \\
\text { d } 249 \text { to } 294\end{array}$ & $\begin{array}{l}\text { September } 5 \text { to October } 20 \\
\text { d } 249 \text { to } 294\end{array}$ \\
\hline Calve cows & $\begin{array}{l}\text { March } 15 \text { to May } 14 \\
\text { d } 75 \text { to } 135\end{array}$ & $\begin{array}{l}\text { June } 15 \text { to July } 30 \\
\text { d } 167 \text { to } 212\end{array}$ & $\begin{array}{l}\text { June } 15 \text { to July } 30 \\
\text { d } 167 \text { to } 212\end{array}$ \\
\hline Wean calves & $\begin{array}{l}\text { September } 16 \text { to October } 5 \\
\text { d } 260 \text { to } 279\end{array}$ & $\begin{array}{l}\text { January } 5 \text { to } 14 \\
\text { d } 5 \text { to } 14\end{array}$ & $\begin{array}{l}\text { January } 5 \text { to } 14 \\
\text { d } 5 \text { to } 14\end{array}$ \\
\hline Move yearlings to grass & 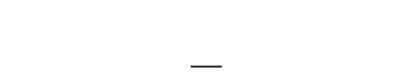 & 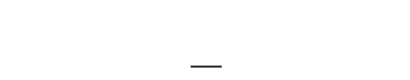 & $\begin{array}{l}\text { May } 28 \text { to June } 8 \\
\text { d } 149 \text { to } 160\end{array}$ \\
\hline Move steers to feedlot & $\begin{array}{l}\text { November } 9 \text { to } 17 \\
\text { d } 314 \text { to } 322\end{array}$ & $\begin{array}{l}\text { February } 10 \text { to } 16 \\
\text { d } 41 \text { to } 47\end{array}$ & $\begin{array}{l}\text { September } 8 \text { to } 16 \\
\text { d } 252 \text { to } 260\end{array}$ \\
\hline Harvest finished animals & $\begin{array}{l}\text { May } 3 \text { to June } 15 \\
\text { d } 124 \text { to } 167\end{array}$ & $\begin{array}{l}\text { August } 8 \text { to September } 9 \\
\text { d } 221 \text { to } 253\end{array}$ & $\begin{array}{l}\text { January } 4 \text { to February } 4 \\
\text { d } 4 \text { to } 35\end{array}$ \\
\hline
\end{tabular}

\footnotetext{
${ }^{1}$ Bulls were placed with cows for $60 \mathrm{~d}$ so full-term calves would be born beginning March 15.

${ }^{2}$ Bulls were placed with cows for $45 \mathrm{~d}$ so full-term calves would be born beginning June 15.

${ }^{3}$ Calf-feds are animals that are moved into the feedlot for finishing soon after they are weaned.

${ }^{4}$ Yearling animals were allowed to graze rangeland for one summer after weaning prior to being moved into the feedlot for finishing.
}

the analysis because all other equipment was considered identical for each of the systems. Based on research at the University of Nebraska's Gudmundsen Sandhills Laboratory (GSL), it was determined that the same land base (about $90 \%$ upland and $10 \%$ subirrigated meadows) could support equivalent numbers of cows year-round for either the March- or June-calving system. Therefore, land charges and taxes and building requirements were considered identical for the 2 systems and so were not included in the budgets. The March-calving system used the meadows for hay production, whereas the June-calving systems used the meadows for summer, spring, and fall grazing.
The major costs for producing a weaned calf are those necessary to support the cow enterprise (Selley et al., 2001). The hay cost, $\$ 44 /$ metric ton, was based on budget estimates for harvesting ( $\$ 33 /$ metric ton) and feeding ( $\$ 11 /$ metric ton), excluding labor. These figures included ownership costs for interest and depreciation on the equipment. Labor costs

\section{Table 2. Pregnancy rate and weaning rate (percentage of cows exposed to the bull) of cows bred to start calving March 15 and June $15^{1}$}

\begin{tabular}{|c|c|c|c|c|c|c|}
\hline \multirow[b]{3}{*}{ Item } & & & \multicolumn{4}{|c|}{ Begin calving June 15 (d 167) } \\
\hline & \multicolumn{2}{|c|}{ Begin calving March 15 (d 75) } & \multicolumn{2}{|c|}{ Range-bred cows } & \multicolumn{2}{|c|}{$\begin{array}{c}\text { Meadow-bred } \\
\text { cows }\end{array}$} \\
\hline & Avg \% & SD & Avg \% & SD & Avg \% & SD \\
\hline Pregnancy rate ${ }^{2}$ & 95.0 & 0.0247 & 92.9 & 0.0336 & 94.0 & 0.0526 \\
\hline Weaning rate ${ }^{3}$ & 88.7 & 0.0462 & 89.9 & 0.0654 & 90.7 & 0.0810 \\
\hline
\end{tabular}

${ }^{1}$ The breeding season was $60 \mathrm{~d}$ for the March-calving and $45 \mathrm{~d}$ for the June-calving systems.

${ }^{2}$ Number of cows that tested pregnant divided by the number of cows exposed to bulls during the breeding season as per Standardized Performance Analysis guidelines (McGrann, 2000). Differences between groups are not significant using ANOVA $(P=0.81)$

${ }^{3}$ Number of cows that weaned a calf divided by the number of cows exposed to bulls during the breeding season as per Standardized Performance Analysis guidelines (McGrann, 2000). Differences between groups are not significant using ANOVA $(P=0.93)$. 
Table 3. Average resource use per head for March-born ${ }^{1}$ and June-born ${ }^{2}$ calf-fed $^{3}$ and yearling ${ }^{4}$ steers

\begin{tabular}{|c|c|c|c|c|c|}
\hline \multirow[b]{3}{*}{ Resource use } & \multirow[b]{3}{*}{$\frac{\text { March }}{\text { Calf-feds }}$} & \multicolumn{4}{|c|}{ June } \\
\hline & & \multicolumn{2}{|c|}{ Calf-feds } & \multicolumn{2}{|c|}{ Yearlings } \\
\hline & & $\begin{array}{l}\text { Range-bred } \\
\text { cows }\end{array}$ & $\begin{array}{l}\text { Meadow-bred } \\
\text { cows }\end{array}$ & $\begin{array}{l}\text { Range-bred } \\
\text { cows }\end{array}$ & $\begin{array}{l}\text { Meadow-bred } \\
\text { cows }\end{array}$ \\
\hline \multicolumn{6}{|l|}{ Cows } \\
\hline Hay (metric tons) & 1.79 & 0.10 & 0.10 & 0.10 & 0.10 \\
\hline Protein supplement $(\mathrm{kg})$ & 44 & 70 & 70 & 70 & 70 \\
\hline Range-grazed $(d)$ & 233 & 207 & 162 & 207 & 162 \\
\hline Meadow-grazed (d) & - & 150 & 195 & 150 & 195 \\
\hline Feeding labor $(\mathrm{h})$ & 0.66 & 0.18 & 0.18 & 0.18 & 0.18 \\
\hline Calving labor $(\mathrm{h})$ & 0.57 & 0.3 & 0.3 & 0.3 & 0.3 \\
\hline \multicolumn{6}{|c|}{ Steers (from weaning until moved to summer grazing or the feedlot) } \\
\hline Hay (metric tons) & - & 0.20 & 0.20 & 0.72 & 0.72 \\
\hline Protein supplement $(\mathrm{kg})$ & - & 48 & 48 & 170 & 170 \\
\hline Ranqe-grazed $(d)$ & 49 & - & - & 31 & 31 \\
\hline Feeding labor (h) & - & 0.15 & 0.15 & 0.53 & 0.53 \\
\hline \multicolumn{6}{|c|}{ Yearlings (from the beginning of summer grazing until moved to the feedlot) } \\
\hline Range-grazed (d) & - & - & - & 102 & 102 \\
\hline Feedlot (d) & 191 & 189 & 189 & 134 & 134 \\
\hline \multicolumn{6}{|c|}{ 'Bulls were placed with cows for $60 \mathrm{~d}$ so full-term calves would be born beginning March 15 . } \\
\hline \multicolumn{6}{|c|}{${ }^{2}$ Bulls were placed with cows for $45 \mathrm{~d}$ so full-term calves would be born beginning June 15 . } \\
\hline \multicolumn{6}{|c|}{${ }^{3}$ Calf-feds are animals that are moved into the feedlot for finishing soon after they are weaned. } \\
\hline \multicolumn{6}{|c|}{$\begin{array}{l}{ }^{4} \text { Yearling steers were allowed to graze rangeland for one summer after weaning prior to being moved into the feedlot for } \\
\text { finishing. }\end{array}$} \\
\hline
\end{tabular}

included in the budgets were based on actual labor for feeding and calving as recorded by the University staff at GSL. Feeding methods, distances to livestock from feed sources, and herd size at GSL are such that we believe labor to be representative of cow-calf producers in the Nebraska Sandhills. Labor was charged at the rate of $\$ 7.50 / \mathrm{h}$ except calving labor, which was charged $\$ 11.25 / \mathrm{h}$ because calving requires more skill than other activities and often occurs at night. No other labor was included in cow budgets because it was assumed that all other labor would be similar between the systems. Purchased feeds (i.e., protein supplement, salt, and minerals) were charged on actual usage, again based on 1998 prices. Interest on the value of cows and bulls was charged at the rate of $7.5 \%$.

Following Standardized Performance Analysis guidelines
(McGrann, 2000), replacement heifer costs were estimated from the net cost to produce a weaned calf. The initial selection rate was $20 \%$ of the heifer calves with $16 \%$ of these heifers ending up in the cow herd. No other heifer development costs were included. Creighton (2004) showed that these costs vary considerably based on development strategies and the quality of available forage. We assumed these costs would be similar between the systems.

Each cow-cost budget was credited with income for sale of cull cows, bulls, and cull replacement heifers, minus death loss. Both March and June cull cows were assigned a cull weight of $500 \mathrm{~kg}$. The prices used for calculating cull values were different for the March and June cows based on seasonal average cull cow prices (Feuz and Burgener, 2005) and the time culling took place.
Grazing costs, not including land cost, were estimated at $\$ 4 / \mathrm{mo}$ per cow when grazing upland range and $\$ 6 /$ mo per cow while grazing meadow. These are financial costs only and cover such items as repair and upkeep on fences and watering facilities and operating costs associated with checking cattle. To properly graze meadows, more fencing and water facilities were required than with upland range. The costs do not include the value of the forage. Animal health costs were similar between the 2 systems and \$15/ cow was included in both budgets.

Costs beyond weaning were based on the actual amounts of feed fed and the associated labor. The grazing fee used for the June-born steers (yearlings) grazing rangeland during the summer was $\$ 0.50 / \mathrm{d}$ per head. This cost covered renting additional grass where the landowner provided labor and pasture management. 
Table 4. Averages and SD of weights and ADG for March-born ${ }^{1}$ and June-born ${ }^{2}$ steers and heifers where steers were moved to the feedlot at weaning

\begin{tabular}{|c|c|c|c|c|c|c|c|c|c|c|c|c|}
\hline \multirow[b]{4}{*}{ Item } & & & & & \multicolumn{8}{|c|}{ June } \\
\hline & \multicolumn{4}{|c|}{ March } & \multicolumn{4}{|c|}{ Range-bred cows } & \multicolumn{4}{|c|}{ Meadow-bred cows } \\
\hline & \multicolumn{2}{|c|}{ Steers } & \multicolumn{2}{|c|}{ Heifers } & \multicolumn{2}{|c|}{ Steers } & \multicolumn{2}{|c|}{ Heifers } & \multicolumn{2}{|c|}{ Steers } & \multicolumn{2}{|c|}{ Heifers } \\
\hline & Avg & SD & Avg & SD & Avg & SD & Avg & SD & Avg & SD & Avg & SD \\
\hline Birth $w^{3}$ & 43 & 2.1 & 40 & 1.5 & 43 & 3.1 & 40 & 2.8 & 44 & 3.0 & 39 & 2.4 \\
\hline Weaning $w t^{4}$ & 220 & 11.4 & 211 & 13.1 & 189 & 11.2 & 183 & 11.7 & 199 & 17.0 & 191 & 10.1 \\
\hline Beginning feedlot $w t^{5}$ & 235 & 9.5 & - & - & 198 & 13.0 & - & - & 209 & 16.0 & - & - \\
\hline Feedlot ADG ${ }^{6}$ & 1.58 & 0.14 & - & - & 1.68 & 0.16 & - & - & 1.61 & 0.13 & - & - \\
\hline Harvest live $\mathrm{wt}^{7}$ & 534 & 16.9 & - & - & 510 & 30.1 & - & - & 509 & 18.6 & - & - \\
\hline
\end{tabular}

${ }^{1}$ Bulls were placed with cows for $60 \mathrm{~d}$ so full-term calves would be born beginning March 15 .

${ }^{2}$ Bulls were placed with cows for $45 \mathrm{~d}$ so full-term calves would be born beginning June 15.

${ }^{3}$ Differences between steers groups $(P=0.84)$ and heifers groups $(P=0.69)$ are not significant.

${ }^{4}$ The ANOVA indicates that significant differences exist between the 3 groups of steers $(P=0.01)$ and the 3 groups of heifers $(P=0.01)$. Student $t$-tests show the difference between March steers and June range steers is significant $(P=0.003)$ and between March steers and June meadow steers is significant $(P=0.06)$, and the difference between the June range and June meadow group is not significant $(P=0.30)$. Differences between the March heifers and June range heifers is significant $(P=$ 0.009) and between March heifers and June meadow heifers is significant $(P=0.03)$. The difference between the June range and June meadow heifers was not significant $(P=0.29)$.

${ }^{5}$ The ANOVA indicates that significant differences exist between the 3 groups of steers $(P=0.01)$. Student $t$-tests show that differences between March steers and June range steers is significant $(P=0.01)$ and between March steers and June meadow steers is significant $(P=0.05)$. The difference between June range and June meadow steers is not significant $(P=$ $0.31)$.

${ }^{6}$ The ANOVA indicates that differences between the ADG is not significant $(P=0.64)$.

${ }^{7}$ The ANOVA indicates that differences between the ADG is not significant $(P=0.26)$.

Table 5. Averages and standard deviations for BW and ADG of June-born ${ }^{1}$ steers that were grazed the summer following weaning before being moved into the feedlot

\begin{tabular}{|c|c|c|c|c|}
\hline \multirow[b]{2}{*}{ Production phase } & \multicolumn{2}{|c|}{ Range-bred cows } & \multicolumn{2}{|c|}{ Meadow-bred cows } \\
\hline & Avg (kg) & SD & Avg (kg) & SD \\
\hline Weaning wt (same as Table 4) & 189 & 11.2 & 199 & 17.0 \\
\hline ADG weaning to summer grazing ${ }^{2}$ & 0.46 & 0.18 & 0.51 & 0.21 \\
\hline Wt beginning summer grazing ${ }^{3}$ & 262 & 28.3 & 281 & 37.2 \\
\hline ADG while summer grazing ${ }^{4}$ & 0.73 & 0.10 & 0.60 & 0.17 \\
\hline Wt beginning feedlot ${ }^{5}$ & 335 & 21.7 & 341 & 19.1 \\
\hline ADG in feedlot 6 & 1.82 & 0.21 & 1.84 & 0.21 \\
\hline Harvest live $\mathrm{wt}^{7}$ & 574 & 23.7 & 584 & 21.8 \\
\hline
\end{tabular}

${ }^{1}$ Bulls were placed with cows for $45 \mathrm{~d}$ so full term calves would be born beginning June 15 .

${ }^{2}$ ANOVA indicates that differences between the ADG is not significant $(P=0.74)$.

${ }^{3}$ ANOVA indicates that differences between the ADG is not significant $(P=0.44)$.

${ }^{4}$ ANOVA indicates that differences between the ADG is not significant $(P=0.25)$.

${ }^{5}$ ANOVA indicates that differences between the ADG is not significant $(P=0.66)$.

${ }^{6}$ ANOVA indicates that differences between the ADG is not significant $(P=0.88)$.

${ }^{7}$ ANOVA indicates that differences between the ADG is not significant $(P=0.56)$. 
Feedlot costs used actual amounts of feed fed at the University of Nebraska feedlot near Mead, Nebraska. Diets were identical for all groups. Ingredient costs were based on 1998 prices plus a $\$ 0.022 / \mathrm{kg}$ trucking charge to and from the feedlot. Feedlot costs also include a $\$ 0.30 / \mathrm{d}$ per head yardage charge.

The costs beyond weaning for calf-fed and yearling steers were calculated in 2 ways. One method simply carried costs forward as they were incurred through the 3 phases of production. This method is representative of a producer retaining ownership of the cattle from birth to harvest. The second method is representative of cattle moving through the market where the production phases, weaning (phase 1), postweaning prefeedlot (phase 2 ), and feedlot (phase 3) are separate enterprises. This second method of cost used the average market value of the calf at the end of the previous phase plus the cost of the current phase as the total cost for that phase.

Table 6 shows the average net returns associated with each of the above mentioned cost methods. The first method is net returns (RO), where RO implies retained ownership; the second method is net returns (To Phase), where To Phase indicates the market valuation method. Gross revenues were calculated by multiplying the average steer weight at the end of each production phase by the average of the 1992 through 1999 market prices, adjusted to 1998 dollars, using the consumer price index published by the US Bureau of Labor Statistics (2007); original prices were taken from Feuz and Burgener (2005). The 2 net returns for each of the systems, found in Table 6 , for each of the 3 production phases were calculated as the difference between the gross revenue per calf and the cost of growing the calf during that particular phase.

\section{RESULTS AND DISCUSSION}

Matching cow nutrient requirements by manipulating calving date to match nutrients available from range and meadow grazing permitted the amount of hay fed (Table 3) to be substantially reduced without significant impacts on pregnancy and weaning rates (Table 2). Marchcalving cows had a pregnancy rate of $95.0 \%$ and a weaning rate of $88.7 \%$, whereas the June-calving cows on range had a pregnancy rate of $92.9 \%$ and a weaning rate of $89.9 \%$, and those on meadow had a $94.0 \%$ pregnancy rate and a $90.7 \%$ weaning rate. Analysis of variance and student $t$-tests showed that calffeds from the March system had a greater $(P=0.01)$ weaning weight $(220 \mathrm{~kg})$ and feedlot entry weight $(235 \mathrm{~kg}$ ) than June system calf-feds, which had weaning weights of 189 and $199 \mathrm{~kg}$ and feedlot entry weights of 198 and $209 \mathrm{~kg}$ for range- and meadow-bred cows, respectively (Table 4). The lighter weight of the June-born calves compared with March-born calves is best explained by smaller, late season calf gains produced on forages lower in digestibility and protein content typical of Sandhills range during November through January (Lardy et al. 1997).

The annual average amount of hay fed to March-calving cows in the $5 \mathrm{yr}$ from 1993 to 1999 was approximately 1.8 metric tons/yr per cow compared with 0.1 metric tons/yr per cow for June-calving cows. However, the June-calving cows received about $26 \mathrm{~kg} / \mathrm{yr}$ more protein supplement per cow than March-calving cows. Labor for feeding and calving to produce a

weaned calf in the June system was $61 \%$ less than the March system (Table 3). A building commonly used for calving in the traditional March system was not needed in the June system. The cost savings associated with not having this building were not included in the analysis but certainly could be considered when making a decision in which season to calve.

Post-weaning (phase 2) feed inputs for calf-fed steers were higher in the June system than the March system, which is a result of both their smaller size and the season when they were weaned. Marchborn steers grazed subirrigated meadow pasture between weaning and feedlot placement whereas June-born steers were fed hay and protein supplement.

June-born steers held over as yearlings to graze the summer following being weaned required more supplement, harvested forage, and grazing than either the June- or March-born calf-fed steers but required about 8 wk less time in the feedlot. The analysis of variance showed no differences $(P=0.10)$ for ADG in the feedlot and harvest weights for either the calf-feds as a group or the yearlings as a group. The calf-fed group averaged from $1.58 \mathrm{~kg} /$ steer per day and a harvest weight of 534 $\mathrm{kg}$ for the March-born steers, to 1.68 and $1.61 \mathrm{~kg} /$ steer per day and harvest weights of 510 and $509 \mathrm{~kg}$ for the June-born steers, range and meadow treatment respectively. The feedlot performance of the yearling group of June-born steers averaged $1.82 \mathrm{~kg} /$ steer per day with a harvest weight of $574 \mathrm{~kg}$ for the range treatment and $1.84 \mathrm{~kg} /$ steer per day and a harvest weight of $584 \mathrm{~kg}$ for the meadow treatment. A greater percentage of the carcasses from the March-born calf-feds graded choice (53\%) than those of the June-born calf-feds (33\%). The June-born yearling steers had the largest percentage of carcasses $(66 \%)$ that graded choice (Table 7). Carcass yield grades were 3 or less for steers in all systems.

The initial motivation for changing the calving season was based on the idea that the June calving season provided a better match for the cyclical nutrient requirements of the cow with seasonally available nutrients from grazed forages in the Nebraska Sandhills. However, as the 
Table 6. Financial analysis of March-born ${ }^{1}$ and June-born ${ }^{2}$ steers by feeding program, breeding treatment, and production phase

\begin{tabular}{|c|c|c|c|c|c|}
\hline \multirow[b]{2}{*}{$\begin{array}{l}\text { Calving season and } \\
\text { feeding program }\end{array}$} & \multirow[b]{2}{*}{$\begin{array}{l}\text { Breeding } \\
\text { treatment }\end{array}$} & \multirow[b]{2}{*}{$\begin{array}{l}\text { Financial } \\
\text { parameter }\end{array}$} & \multicolumn{3}{|c|}{ Production phase } \\
\hline & & & $\begin{array}{c}\text { To weaning } \\
(\$)\end{array}$ & $\begin{array}{l}\text { Weaning to } \\
\text { feedlot }(\$)\end{array}$ & $\begin{array}{l}\text { Feedlot to } \\
\text { harvest }(\$)\end{array}$ \\
\hline \multicolumn{6}{|l|}{ March } \\
\hline \multirow[t]{5}{*}{ Calf-fed } & & Ending calf value ${ }^{5}$ & 443.88 & 456.39 & 844.69 \\
\hline & & Cost for this phase & 252.00 & 42.00 & 286.00 \\
\hline & & Cost to phase end & 252.00 & 294.00 & 580.00 \\
\hline & & Net return (To Phase) ${ }^{6}$ & - & -29.49 & 102.30 \\
\hline & & Net return $(\mathrm{RO})^{7}$ & 191.88 & 162.39 & 264.69 \\
\hline \multicolumn{6}{|c|}{ 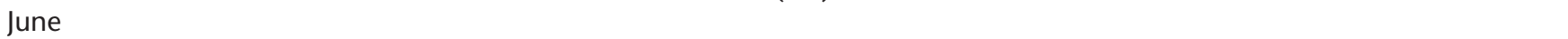 } \\
\hline \multirow[t]{10}{*}{ Calf-fed } & Range-bred cows & Ending calf value & 426.08 & 454.62 & 783.64 \\
\hline & & Cost for this phase & 173.00 & 46.00 & 286.00 \\
\hline & & Cost to phase end & 173.00 & 219.00 & 505.00 \\
\hline & & Net return (To Phase) & - & -17.46 & 43.02 \\
\hline & & Net return (RO) & 253.08 & 235.62 & 278.64 \\
\hline & Meadow-bred cows & Ending calf value & 443.01 & 470.61 & 782.10 \\
\hline & & Cost for this phase & 178.00 & 47.00 & 286.00 \\
\hline & & Cost to phase end & 178.00 & 225.00 & 511.00 \\
\hline & & Net return (To Phase) & - & -19.40 & 25.50 \\
\hline & & Net return (RO) & 265.01 & 245.61 & 271.10 \\
\hline \multirow[t]{10}{*}{ Yearling-fed } & Range-bred cows & Ending calf value & 426.08 & 609.00 & 933.31 \\
\hline & & Cost for this phase & 173.00 & 209.00 & 254.00 \\
\hline & & Cost to phase end & 173.00 & 382.00 & 636.00 \\
\hline & & Net return (To Phase) & - & -26.08 & 70.32 \\
\hline & & Net return $(\mathrm{RO})$ & 253.08 & 227.00 & 297.31 \\
\hline & Meadow-bred cows & Ending calf value & 443.01 & 612.66 & 949.57 \\
\hline & & Cost for this phase & 178.00 & 211.00 & 254.00 \\
\hline & & Cost to phase end & 178.00 & 389.00 & 643.00 \\
\hline & & Net return (To Phase) & - & -41.35 & 82.91 \\
\hline & & Net return (RO) & 265.01 & 223.66 & 306.57 \\
\hline
\end{tabular}

\footnotetext{
${ }^{1}$ Bulls were placed with cows for $60 \mathrm{~d}$ so full-term calves would be born beginning March 15.

${ }^{2}$ Bulls were placed with cows for $45 \mathrm{~d}$ so full-term calves would be born beginning June 15 .

${ }^{3}$ Calf-fed steers were moved to the feedlot within $60 \mathrm{~d}$ of weaning and yearlings were grazed on rangeland the summer following weaning before being moved to the feedlot.

${ }^{4}$ Land costs are not included in this analysis.

${ }^{5}$ Calf value was calculated by multiplying the average steer weight and the monthly average steer price for comparable weight steers over an 8-yr period.

${ }^{6}$ To Phase refers to a method to determine costs beyond weaning for calf-fed and yearling steers that uses the average market value of the calf at the end of the previous phase plus the cost of the current phase as the total cost for that phase ${ }^{7} \mathrm{RO}$ stands for retained ownership, one method to determine costs beyond weaning for calf-fed and yearling steers, is the return for the phase in question in excess of the accumulated costs for all phases up to and including the one being analyzed.
}

comparison between calving periods was made, it became clear that the interaction of factors both biological and economic were the real driving forces in the calving season decision.

To illustrate this point, the March-born calves weaned at an average heavier weight, about $24 \mathrm{~kg} /$ steer, but because of the larger calf size and seasonal market differences, an 11\% higher per kilogram price was received for the June-born calves. The seasonal premium at weaning accounted for approximately $63 \%$ of the higher price, and the price slide associated with size difference accounted for the re- maining $37 \%$ of the premium gained by the June-born steer calves. These premiums helped mitigate the gap in calf weaning weight and calf value between the Juneand March-born calves, resulting in the June-born range-treated steers being valued at $\$ 17.80$ less per animal, and the June-born meadow- 
treated steers being valued at $\$ 0.87$ less per animal. Given similar valuation at weaning of the seasonally separated steers implied that any difference in cost between the systems would be the primary factor that would determine differences in net returns. In this case, the June-born steers had lower cost: $\$ 79 /$ steer for the range treatment and $\$ 74 /$ steer for the meadow treatment. The June-born range treatment had a $\$ 5 /$ steer lower cost than the Juneborn meadow treatment, but on average produced lighter weight weaned calves resulting in a $\$ 16.93$ difference. The overall outcome of these interactions gave the Juneborn range and meadow treatments a $\$ 61.20$ and $\$ 73.13 /$ steer respectively net return (RO) advantage over the March-born calving system to the end of phase 1 . These results demonstrate the interaction of cost, seasonal price differences, and overall resource allocation on net returns (RO) when considering alternative calving systems. In this case the disadvantage of selling lighter weight calves was partially offset because of the seasonally higher market price and price slide. If the additional benefits of reduced costs are included, higher net returns (RO) result for the June-born calving system. The associated cost and net returns are summarized in Table 6.

The additional financial costs associated with growing a steer calf past weaning were nearly the same for both the June- and March-born calf-fed systems; therefore, the financial cost advantage remained with the June system through the feedlot phase for the net returns (RO) for all treatments and production phases (Table 6). Interestingly the advantage in net returns that the meadow treatment had over the range treatment for the June-born calf-feds disappeared in phase 3 . This advantage appears to be the result of compensatory gains made by the range treatment steers in the feedlot. The yearling results, however, are quite different and show that the June-born meadow-treated steers finished $10 \mathrm{~kg} /$ head heavier than the range-treated contemporaries.

As the calf-fed steers progressed through each phase of production, the net returns (RO) steadily decreased. By the time the steers reach market size, the seasonal price and size differences narrowed the net returns (RO) to $\$ 13.95$ and $\$ 6.41$ / head between the March-born steers and the June-born range-treated and meadow-treated calf-fed steers, respectively. It should be remembered that the net returns from the weaning phase do not include the costs of property taxes, buildings, insurance, and land cost. Although these costs are the same for each of the systems and their exclusion has no effect on the net return rankings of the systems, their inclusion would have reduced the magnitude of the weaning phase net returns, making them comparable between phases. The large net returns (RO) in phase 1 makes this phase appear more attractive compared with the other 2 phases. However, without including the omitted costs, no comparisons between phases can or should be made.

As steers move through the phases of production from weaning to feedlot, all June-born calving systems and treatments had higher net return (RO) when compared with the March-born system (Table 6). However this was not true of the net return (To Phase). Phase 2 had mixed results, with all systems and treatments having a negative net return (To Phase). The June-born calffeds were less negative than the March-born calf-feds, but the Juneborn yearlings had a larger negative net return (To Phase). The negative net return (To Phase) for phase 2 indicates that buying and holding steers was unprofitable for all systems and treatments. Given the cost and production assumptions made here, the least unprofitable system was the June-born calf-fed range-treated steers. Again, this ef- fect is the result of the interaction of season, cost, and calf weight. In the final phase of production, the March-born steer's net return (To Phase) exceeded all of the Juneborn systems and treatments. This result is due to the seasonal price, cost, and steer weight differences only, because harvest weight animals were not considered to have a price slide. These results are based on market quoted prices for slaughter cattle and do not include quality grade and yield premiums and discounts. If these premiums and discounts were included in the analysis, the June-born yearlings would have had an advantage, having the largest percent choice, possibly altering the results. The June-born calffeds had the least number of animals that would have qualified for the choice premium, insuring that they probably would have maintained their status as the lowest net return (To Phase) systems. The net return (To Phase) for phase 3 , given the cost and production assumptions, indicate that a feedlot's operators who buy cattle would have done better with March-born steers then with steers from any of the other systems.

\section{IMPLICATIONS}

Changing the beginning of the calving season from March 15, d 75 , to June 15 , d 167, to match cyclical nutrient requirements of cows to seasonal nutrient availability from available forages dramatically reduced the quantity of hay fed without impacting subsequent pregnancy rates and calf numbers. Some additional purchased feeds were required in the June-born calving systems. Cost and return analysis showed production costs for steers from the June-born calf-fed systems were lower and net returns ( $\mathrm{RO})$ for all June-born systems and treatments were higher than for the March-born system. Not all systems were equal in net returns (To Phase) and those buying cattle for resale, 
the holding phase, should consider carefully size, season, and length of holding cattle. Retained ownership through harvest was not investigated, but the information collected here indicates it could alter the net return (RO) rankings for that phase of production. The results here also indicate that the real advantage to changing calving season accrues to producers who sell weaned calves. If weaned steers are held and sold later, the cost difference narrows and seasonal price differences erode, making it less advantageous to change calving season from March to June.

Consideration of an alternative calving season is a complex decision and includes changes in physical and economic relationships and outcomes as well as implicit differences in management and resource allocations. Although we interpreted these data to indicate that financial gains may be possible with chronologically later calving, any changes in an individual's operation need to be considered carefully and as completely as possible, remembering that the impact of this one choice of when to calve in- cludes the consideration of many changes in management, resource usage and allocation, benchmark performances, and marketing strategies.

\section{LITERATURE CITED}

Adams, D. C., R. T. Clark, T. J. Klopfenstein, and J. D. Volesky. 1996. Matching the cow with forage resources. Rangelands 18:57.

Clark, R. T., R. K. Wilson, D. C. Adams, J. D. Volesky, and R. E. Sandberg. 2004. Breeding and feeding management - practices used by cow-calf producers in western and north central Nebraska. Res. Bull. 346. Agricultural Research Division, Institute of Agriculture and Natural Resources, University of Nebraska, Lincoln. 58p.

Creighton, K. W. 2004. Heifer development systems for March-born heifers and improving pregnancy rates in June-calving cows.

Ph.D. dissertation, University of Nebraska, Lincoln.

Deutscher, G. H., J. A. Stotts, and M. K. Nielsen. 1991. Effects of breeding season length and calving season on range cow productivity. J. Anim. Sci. 69:3453.

Feuz, D. M., and P. A. Burgener. 2005. Historical cattle and beef prices, seasonal patterns and futures basis for Nebraska, 19602004. PHREC 05-21. Univ. Nebraska-Lincoln, Coop. Ext. Serv.

Klopfenstein, T. J. 1991. Low-input, high-forage beef production. In Sustainable Agriculture Research and Education in the Field: A
Proceedings. T. L. Huller, ed. Natl. Acad. Press, Washington, DC.

Lardy, G., D. Adams, T. Klopfenstein, D. Clark, and J. Lamb. 1997. Seasonal changes in protein degradabilities of Sandhills native range and subirrigated meadow diets and application of a metabolizable protein system. 1997 Beef Cattle Report. p 3. Agricultural Research Division. University of Nebraska, Lincoln.

Mader, T. L., O. A. Turgeon, Jr., T. J. Klopfenstein, D. R. Brink, and R. R. Oltjen. 1989. Effects of previous nutrition, feedlot regimen and protein level on feedlot performance of beef cattle. J. Anim. Sci. 67:318.

May, G. J., L. W. Van Tassell, M. A. Smith, and J. W. Waggoner. 1999. Delaying calving and reducing winter feed costs: Case studies of Wyoming producers. B-1076. Univ. Wyoming, Coop. Ext. Serv., Laramie.

McGrann, J. M. 2000. Cow-Calf Standardized Performance Analysis (SPA) Handbook and Software User Manual. Texas A\&M University, Department of Agricultural Economics, Texas Agric. Ext. Serv., College Station.

Selley, R. A., T. Barrett, L. L. Bitney, R. T.

Clark, D. Feuz, and H. D. Jose. 2001. Nebraska Livestock Budgets. Ext. Circ. 01-818S. University of Nebraska, Coop. Ext. Serv., Lincoln.

USDA. 2000. Agricultural Prices - 1990 Summary. Natl. Agric. Stat. Serv. Washington, DC p. A-11.

US Department of Labor. 2007. Consumer Price Index - All Urban Consumers (Current Series). Bureau of Labor Statistics. http:// www.bls.gov/cpi/ Accessed April 18, 2007. 